\title{
SUSTAINING THE ASSYRIAN ARMY AMONG FRIENDS AND ENEMIES IN 714 BCE
}

\author{
John Marriott (Windlesham House School) and \\ Karen Radner (University College London)
}

\begin{abstract}
This study aims to investigate how the Assyrian army functioned and survived while on a campaign in difficult, hostile, mountainous territory by studying the narrative of the campaign led in 714 BCE by Sargon II of Assyria (r. 721-705 BCE) into the northern Zagros mountain range, today the border region between Iraqi-Kurdistan and Iran and beyond. The main focus is on the manner in which the army procures food while cut off from Assyrian supply lines and on the composition of the army, which reflects the nature of this specific campaign.
\end{abstract}

The so-called Letter to the God Aššur of Sargon II, king of Assyria (r. 721-705 BCE) offers an account of his eighth campaign (hence the modern designation as "Sargon's Eighth Campaign," abbreviated here as Sg. $8^{1}$ ), conducted in 714 into the northern Zagros mountain range and against the kingdom of Urartu and its allies. The main theme of this most detailed narrative of a military campaign to have survived from the Neo-Assyrian period is that of an army and its king on campaign in enemy territory, cut off from Assyria. This highly polished work of literature is one example of a particular genre of texts ${ }^{2}$ that, as Oppenheim argued in a classic study, were read out to an audience, acting as an oral report of the campaign to the people of the city of Aššur. ${ }^{3}$ Sargon's "Letter" is addressed to Aššur and the other gods of Assyria, the city of Aššur and the people (Sg.8 lines 1-5) and is full of intense drama, ${ }^{4}$ emphasizing Sargon's valor (e.g., Sg.8 lines 65, 132) and the heroism of his troops (e.g., Sg.8 lines

This study began as a commentary on Sargon's "Letter to the God Aššur" drafted by Marriott for Radner's MA course "Change and Continuity in the Ancient Near East in the First Millennium BC” (2011-2012), which then grew into his MA thesis, written under Radner's supervision. As Marriott's other commitments made it impossible for him to see through the work to publication, Radner completed the study. We thank Lindsay Allen (King's College London) and Hans van Wees (University College London) for their comments, Mario Fales (University of Udine), Grant Frame (University of Pennsylvania), and Matt Purdie (Royal Holloway, University of London) for use of their forthcoming or unpublished work, and Stephan Kroll (University of Munich) for his bibliographical help at very short notice. Abbreviations: An. = Xenophon, Anabasis (quotations after Rex Warner's 1975 translation for Penguin Classics); Cyr. = Xenophon, Cyropaedia; RIMA 1-3 = Grayson 1987, 1991, 1996; RINAP 4 = Leichty 2011; SAA 1 = Parpola 1987; 4 = Starr 1990: 5 = Lanfranchi and Parpola 1990; 15 = Fuchs and Parpola 2001; 17 = Dietrich 2003: 18 = Reynolds 2003: 19 = Luukko 2012.

1. Editio princeps: Thureau-Dangin 1912 (in French). See Foster 2005 (English translation); Frame (in press; full English edition); Mayer 1983 and 2013 (full German editions).

2. Two other examples of this genre of text are known at the present time: one from the reign of Shalmaneser IV (r. 782-773 BCE; RIMA 3 A.0.105.3), and one from the reign of Esarhaddon (r. 680-669 BCE; RINAP 4, 33), although neither is preserved as well as Sargon's. Na'aman 1974 identified a possible additional such text from the reign of Sennacherib (r. 704-681 BCE).

3. Oppenheim 1960: 143-45; although this view has been widely adopted, approval is not universal: Hurowitz 2008 : 108 is cautious to accept such a public reading of the composition while still suggesting that it served "some non-private use."

4. According to an experiment conducted by Matthew Purdie (personal communication) for Radner's MA course (2012-2013), it takes 
$10,25,30)$ as they overcome obstacles and face great danger. While it remains unclear whether the intention of this and other "Letters to the God Aššur" was celebratory or apologetic (or both), the composition undoubtedly served to perpetuate the mythos of the invulnerability of the Assyrian king ${ }^{5}$ and reassured the audience that theirs was the very best army.

Sandwiched between the heroic narratives of the pitched battle against the Urartian forces at Mount Wauš (Sg.8 lines 91-161) and of the conquest of the city of Mușașir (Sg.8 lines 309-348; see Dubovský 2006a), there is an account of the movements of the army across enemy territory which we will use in this article to analyze the logistics employed to allow the army to function there. Like the list of booty taken from Mușașir at the end of the composition (Sg.8 lines 348-407), this part of Sargon's "Letter" is rather more factual than the battle scenes at Mount Wauš and Mușașir that mirror and borrow topoi and imagery from epic compositions. ${ }^{6}$ In order to further assess the accuracy of the claims made in that part of Sg.8, we will contextualise the account with additional, preferably archival sources (i.e., letters and administrative texts), wherever this is possible.

\section{Preparations: The Army in Friendly Territory}

Every Assyrian campaign began with the muster of the army. In $714 \mathrm{BCE},{ }^{7}$ king Sargon set out from the then capital Kalhu sometime in late June or early July, corresponding to the Assyrian month of Du'uzu (no day date is given), and headed east to the province of Mazamua to review the forces that had assembled there (Sg.8 lines 6-12). Summer may seem rather late to begin a campaign into mountainous areas, particularly because the army would have needed to return to the western slope of the Zagros by November at the very latest, as snow would make the mountain routes impassable and potentially deadly. ${ }^{8}$ However, there are a number of reasons for a summer departure. Firstly, only at that time the mountain routes over the Zagros were completely clear of snow: some passes used by the Assyrians, such as the Kelishin pass (located on the modern Iranian-Iraqi border, southwest of Lake Urmia: $36^{\circ} 54^{\prime} \mathrm{N}, 44^{\circ} 55^{\prime} \mathrm{E} ; 2,981 \mathrm{~m}$ altitude), ${ }^{9}$ can be covered with snow as late as July (Wilson 1895: 322; Zimansky 1985: 20). Departing in the summer meant that the army would have had the best possible chance of navigating the mountains successfully. It also meant that the animals collected as tribute from the Zagros kingdoms during the first half of the 714 campaign -in the main vast numbers of horses, cattle, camels, and sheep (Sg.8 lines 35-36; 37-38; 42-50; 55; 70; 306-308) - could travel unhindered through the mountains. Secondly, embarking on the campaign in summer indicates planning concerning the army's provisions when on enemy territory. As we shall see, the granaries of enemy towns were central to the Assyrian army's survival, and as Sargon probably arrived in Urartian territory in early autumn, after the harvest, the granaries would have been full as the inhabitants stored as much grain as possible for the harsh winters. In addition, in September livestock would be moved down from their summer pasture grounds in the highlands to winter pasturage (van Driel 1992: 46), making it an easy target for the Assyrian army, which could not reach it while summering in the mountain meadows.

Mazamua, where Sargon mustered the troops in 714 BCE, was a province located on the northwestern slopes of the Zagros Mountains to the east of the Assyrian heartland and centered on the Shahrizor Plain (today in the

\footnotetext{
forty-six minutes to read the text aloud (in English translation) and the composition manages to hold the attention of a neutral audience without prior knowledge.

5. Who years later died on the battlefield; Fuchs 2009: 59-60.

6. Analyzed, e.g., by Zaccagnini 1981; Fales 1991; Kravitz 2003; and Van De Mieroop 2010.

7. For the political context of the campaign, see the concise discussion in Fuchs 2009: 59.

8. That snow was a serious obstacle in mountainous regions is attested in a number of letters from Sargon's state correspondence, e.g., SAA 5: 126, 146; SAA 15: 60, 83. For a study on snow and its effects on the running of the Assyrian empire, see Van Buylaere 2009. Xenophon describes in his Anabasis the severe dangers caused by snow in the Taurus Mountains, such as snow-blindness, frostbite, and a soldier's shoes freezing to his feet during the night (An. 4.5).

9. Radner 2012: 248. It is very likely that Sargon's forces took this pass on the way back, en route to Muṣașir.
} 
province of Sulaymaniyah, Kurdish Autonomous Region of Iraq). Any province in which the army mustered was under great pressure to provide enough food for the army and fodder for the animals, most importantly horses. On at least one occasion during the reign of Sargon II, the province of Lahiru (situated further to the south on the western fringes of the Zagros) was used as a gathering point for an enormous force headed in an easterly direction, as is revealed by a letter that reports on the potential daily and monthly grain consumption the province could support (SAA 5: 250): 70,500 liters of grain per day, or 2,115,000 liters per month. ${ }^{10}$ Evidence from Sargon's state letters makes it clear that the different components of the army were scheduled to arrive as closely together as possible (e.g., SAA 1: 18, 49, 91). The decentralized nature of the army (Fuchs 2005: 51-55) meant that each commander would have brought his troops to the mustering point, ${ }^{11}$ some via different routes. ${ }^{12}$ Rather than living off the land, troops were given travel provisions for such a journey. ${ }^{13}$

The Shahrizor plain, as a climatically favored and agriculturally very rich region (Altaweel et al. 2012: 6-7), is well suited for the purpose of gathering the army, but in order to limit the pressure on the region it was nevertheless crucial that the troops would not stay for long. Mazamua offers access to a good and relatively easy route across the Zagros via Khurmal and the Hewrman range. ${ }^{14}$ The province is therefore an ideal point of departure for an army preparing for a campaign into the Zagros ${ }^{15}$ and was used routinely in this manner. The inscriptions of Assurbanipal (r. 668-630 BCE) describe the province as a mustering point and entryway into the Zagros region for a campaign against the kingdom of Mannea. ${ }^{16}$ A letter from Sargon's state correspondence (SAA 5: 215) $)^{17}$ gives a provisional headcount of troops assembled in Mazamua, and this may or may not be part of the campaign related in Sg.8.

Once the army was successfully assembled in 714, Sargon moved across the Zagros mountain range into the territory of another Assyrian province: Parsua in the region of modern Sanandaj in Iran's Kurdistan province. ${ }^{18}$ Sargon stayed there for a time and the majority of the vassal kingdoms brought their tribute to Sargon in Parsua (Sg.8 lines 38b-50), substantially relieving the pressure placed upon the province to provide for the army. Its situation on the other side of the Zagros range, whose peaks in that region are in excess of 3,600 m, made Parsua illsuited for the initial muster of troops, as undertaking the difficult crossing at once made far better logistical sense, but it was an excellent place to bring the cavalry forces to full strength. Sg. 8 highlights the difficulties faced by an

10. The number of soldiers that could be fed on this amount of food is uncertain, and depends entirely on whether a soldier's daily ration was 1 qa ( $\approx 1$ liter) or more. According to tentative calculations by Fales 2000: 47-51, this may have fed an army of between 30,000 and 67,000 men. In a more recent paper, Fales has advocated the figure of 30,000 (Fales and Rigo 2014), a view already held in Fales $1990: 31$.

11. As is made clear by the letter from Lahiru, which states that the commander-in-chief, the chief cupbearer, and a number of governors were present, but that the royal entourage and a number of other magnates had not yet arrived: SAA 5: 250 lines 4-13.

12. A letter from the governor of Mazamua explains how he had taken a different route than the governor of Arrapha because the latter's route is slower (SAA 5: 199). The two governors were apparently heading to the province of Parsua, which shows how the army could in fact muster across mountain ranges, travelling independently.

13. 'Travel provisions which they carry with them (i.e., the troops)' are mentioned in a letter from Tubliaš in the Elamite-Babylonian border region dating to the reign of Sargon II (SAA 17: 152 lines 7-9). Esarhaddon, in the account of his accession in his royal inscriptions, makes a special mention that he did not "stock up on travel provisions" for his march to Nineveh in order to secure the throne after Sennacherib's murder, implying that the usual course of action was to do so (RINAP 4, 1 i.65). During the march from Mazamua to Parsua in 714, the soldiers almost certainly carried provisions with them although the account of Sg.8 does not explicitly state this. But we can assume so in analogy to the scenario described for the army's homeward journey through the mountains at the end of the campaign, for it is stated that the troops "joyfully prepared lavish travel provisions for the return march to the land of Assyria" (Sg.8 line 264).

14. Altaweel et al. 2012: 13. Until now, the local inhabitants habitually use this route in order to avoid the border formalities between Iran and Iraq. According to Omar Mohammed Ali (personal communication 2011), guard of Bakr Awa, who has personal experience of the route, it takes about six hours when carrying a load and the route can be managed by donkeys and mules.

15. The importance of Mazamua can be recognised by the relentless campaigns conducted in the area by Adad-nerari II, Assurnașirpal II, and Shalmaneser III. It was finally subdued in 842 by Shalmaneser III (RIMA 3, A.0.102.6, col. iii 53-60); Radner $2006 a$ : 52.

16. Assurbanipal used the fortified stronghold of Dur-Aššur (modern Bar Awa), a city re-founded and renamed by Assurnașirpal II (RIMA 2, A.0.101.1, col. ii 84b-86a), as his base in the province; Borger 1996: 220: Prism B, col. iii 21-22. For the context see Altaweel et al. 2012 : 14.

17. For studies of this letter, see Fales 2000: 40-43, Postgate 2000: 89-108 and our discussion below.

18. The location of Parsua and the other trans-Zagros provinces Bit-Hamban, Harhar (= Kar-Šarrukin), and Kišessim (= Kar-Nergal) is discussed most recently by Radner 2013: 443-47. 
army travelling through mountainous terrain. On the way from Mazamua to Parsua, Mount Simirria's ascent was a challenge as it was "discouraging for the ascent of chariots and to the high spirits of the horses, the worst possible going for the passage of foot soldiers" (Sg.8 lines 22). ${ }^{19}$ To combat this difficulty, Sargon had the vanguard of his army improve the mountain paths, ${ }^{20}$ which allowed the light infantry and baggage train, consisting of both donkeys and camels, to follow (Sg.8 lines 24-26). This feat should not be underestimated. In his Anabasis, Xenophon describes how the Ten Thousand decided to release most of their baggage animals when they were in mountainous terrain, a decision that was also supported by the fact that a large number of baggage animals required a substantial amount of food, which was very hard to come by on such a difficult march (An. 4.1.12-13). This may be why the Assyrians utilized camels as well as mules, because camels have an even greater ability to abstain from food and water than the already frugal mules ${ }^{21}$ capable of going up to fourteen days without water if necessary. They can also carry double the amount of a mule, cope with difficult terrain, and because of their size more comfortably ford rivers (Moorey 1994: 13).

By 714, the Zagros was familiar territory to Sargon and his troops, as they had campaigned in the region in 719, 716 , and $715 . .^{22}$ In the account of Sg.8 (lines 38b-41), it is noted that in 714 a number of vassal kingdoms were in a state of "stillness inspired by awe" (šahurratu, Sg.8 1.40) as their inhabitants remembered the bloody campaign in the previous year and therefore willingly delivered tribute to the Assyrian province of Parsua. The Assyrian forces collected an enormous amount of tribute from the vassal kingdoms of the Zagros at this time, including horses, cattle, sheep, and camels. This part of the 714 campaign appears to have been an attempt at consolidating Assyrian power and authority in the region, and successfully so, as not a single armed conflict took place at this stage of the campaign. The army was not used to fight, but to intimidate: the presence of the king and his warriors, certainly an impressive display of power, was evidently enough to secure tribute. While the majority of this tribute will have been sent back to central Assyria, the Assyrian forces would have consumed some of the animals, especially the sheep, on the spot. The horses, on the other hand, are likely to have been amalgamated with Sargon's army at this point. The expectation of tribute in horses would have allowed Sargon to bring fewer horses from central Assyria into the Zagros, which was, after all, one of the main supply regions of the empire. Far less surefooted than donkeys, mules, and camels, horses are not well suited for mountain treks and moreover need massive amounts of food. ${ }^{23}$ Bringing Sargon's cavalry force to full strength only at the eastern flank of the Zagros significantly lessened the pressure to provide fodder and, equally important, care for the animals on the difficult march across the Zagros main range.

Once the tribute had been received and local loyalties had been reaffirmed, Sargon took his force beyond the Assyrian provincial borders onto vassal territory, to the kingdom of Mannea. Its king Ullusunu was expected to provide for his suzerain's army and "as if he had been one of my own eunuchs or governors of the land of Assyria, had stocked provisions of flour and wine to feed my troops" (Sg.8 lines 53-54). Support was also expected during the creation of an Assyrian base of operations at the fortified city of Panzišs, on the border between Mannea and pro-Urartian Zikirtu, from which Sargon launched his attack into enemy territory. ${ }^{24}$ Control over Panziš had been secured only a year earlier during the campaign of 715 , and as its siege and conquest were commemorated on the

19. Difficult mountain passes are also described on the way back across the Zagros, in Sargon's approach to Muṣașir: Sg.8 lines 330-332.

20. They are said to do so "with copper axes", a literary topos already attested in the inscriptions of Tukulti-Ninurta I (r. 1243-1207 BCE; RIMA 1, A.0.78.23, lines 27-55) and recurring in the inscriptions of later rulers, including Aššur-bel-kala (r. 1073-1056 BCE; RIMA 2, A.0.89.2, col. i.15-18), Assurnașirpal II (r. 883-859 BCE; RIMA 2, A.0.101.1, col. ii.76b-84a; ii.95), and Shalmaneser III (RIMA 3, A.0.102.1, lines $19 \mathrm{~b}-29 \mathrm{a})$

21. Mules and donkeys consume up to 20 liters of water per day and cattle up to 30 liters; Krentz 2008: 162.

22. For an overview of Sargon's Zagros campaigns, see Radner 2003: 50-55; also Fuchs 2009: 55-56.

23. A letter concerning the muster at Kar-Ašsur in Lahiru reports that the province was ready to provide 57,800 liters of fodder per day for pack animals alone (SAA 5: 250); cf. Fales 2000: 48. Note the recent discussion of Kar-Aššur's location and long-term history in Kessler 2013 who considers it possible that the city was not part of Lahiru but instead the center of a homonymous province between the territories of Lahiru and Arrapha (acknowledging, however, that the sources do not directly mention such a province).

24. The city is depicted on a now lost relief from room 14 (slab 2) of the palace at Dur-Šarrukin. The accompanying inscription reads: 


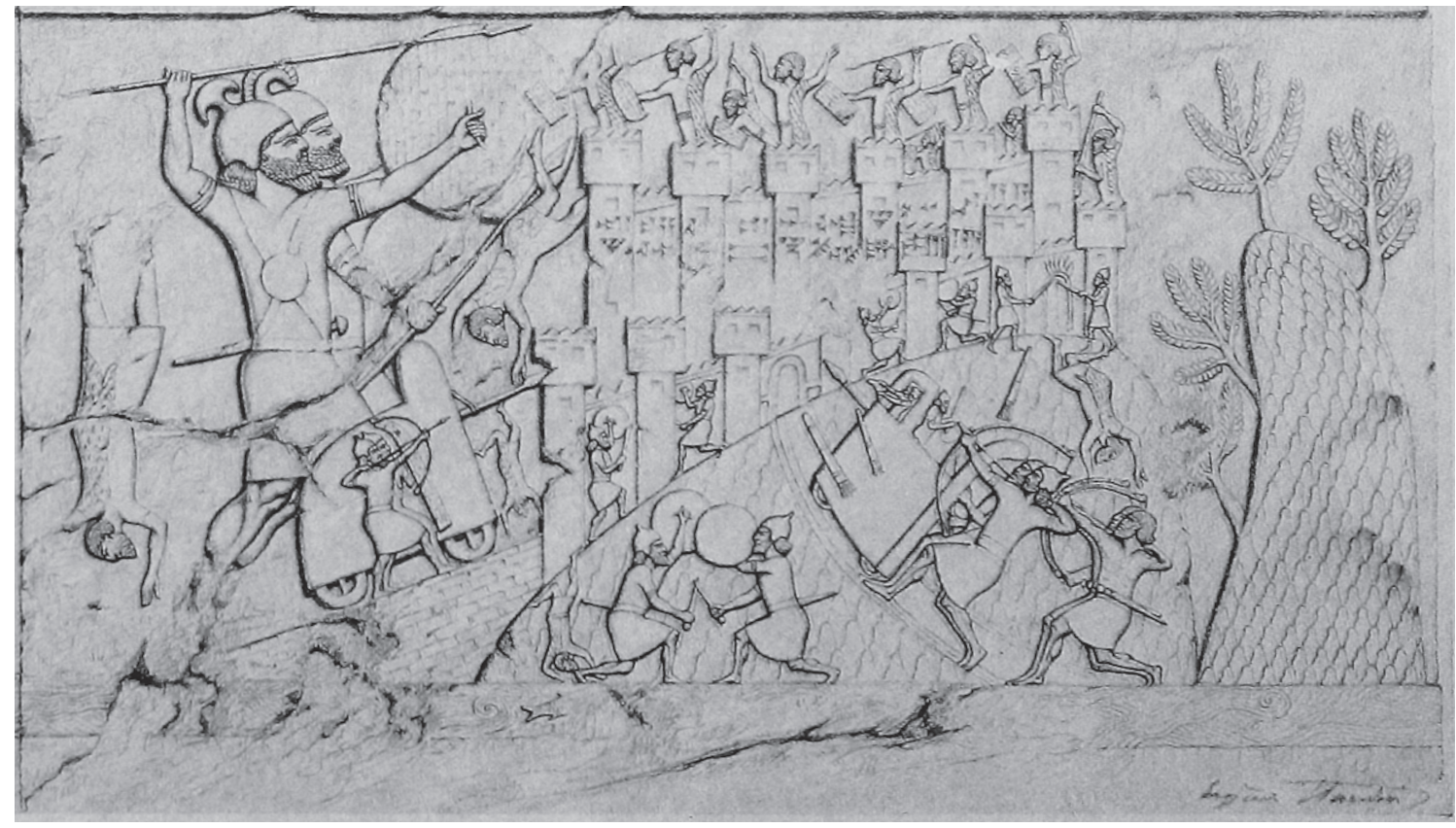

Fig. 1. The Assyrian siege of the Mannean fortress Pazzaši (elsewhere Panziš) in $715 \mathrm{BCE}$, as depicted on a now-lost relief from room 14 (slab 2) of Sargon II's palace at Dur-Šarrukin (modern Khorsabad). After Botta and Flandin (1850) 2:pl. 145.

walls of Sargon II's palace at Dur-Šarrukin, there is an Assyrian depiction of the fortress, which is identified by an accompanying inscription (fig. 1). In 714, the Assyrian forces strengthened the construction of the fortress and "brought into it barley, oil, wine, and military equipment" (Sg.8 line 78). Although the army may have played a part in the building work, there can be little doubt that all the supplies were handed over by Ullusunu, and perhaps by a number of other vassal rulers.

Up to this point, the 714 campaign was of a preparatory nature. Although Sargon was officially on campaign, he never truly left friendly territory, spending time in the Assyrian province of Parsua and in the adjoining lands of his vassals, which meant that beyond the obvious dangers inherent to mountainous terrain there was little concern for the security or wellbeing of the army.

\section{Into the Wild: The Army in Unknown Territory}

The creation of Panziš as an insular Assyrian stronghold was the last stage at which Sargon could prepare, supply, and review his army before he led his troops into enemy territory. Soon after the account of Sargon's departure from Panziš, the reader is treated to a detailed, albeit factually somewhat suspect, description of the only pitched battle in the entire 714 campaign. ${ }^{25}$ Rusa, the king of Urartu, and his allies had assembled for battle in a pass on

\footnotetext{
"Pazzaši (= Panziš), a Mannean fortress, which is in front of the pass leading to the land of the Zikirtean (i.e., Mittati, king of Zikirtu)"; Botta and Flandin 1850, 2:pl. 145 (drawing); Fuchs 1994: 278-79, 364 (inscription).

25. For a study of the tactics used in this battle, see Scurlock 1997: 498-503. However, as Fuchs (2012: 39-42) has demonstrated by comparing the account with the strikingly similar narrative of another of Sargon's battles, fought in 709 at the gates of the southern Mesopotamian city of Dur-Yakin, it is best to take a skeptical view to the source's value for reconstructing the actual fighting.
} 
Mount Wauš, and sent a messenger to Sargon, challenging him to fight (Sg.8 line 111). From the following battle description we learn about the Urartian army. We hear that Rusa personally led his troops and that high officials, counselors, courtiers, eunuchs, provincial governors, and members of the royal family accompanied him (Sg.8 lines 135-140). The Assyrians managed to capture 260 of these high-status individuals (Sg.8 line 138). These prisoners would have been extremely valuable assets in general, but for the time being, they would have served as excellent guides to the Urartian kingdom: a well-travelled provincial governor, for example, would have been able to advise where to camp with an army or gather resources. Sargon had substantial knowledge of Urartu before this, provided by his sophisticated espionage network, ${ }^{26}$ but to have a number of knowledgeable local guides at his disposal must have made a campaign into Urartian-controlled territory seem less daunting and perhaps even attractive. Indeed, we cannot be sure if such an invasion had always been an objective of the 714 campaign, or if it was a reaction to his victory on Mount Wauš. Whatever the original plan may have been, Sargon, having defeated the Urartian king in battle and now in possession of some well-informed and well-connected guides, decided to continue the campaign by marching into regions under the suzerainty of the kingdom of Urartu.

The force that Sargon led into the Zagros, and then on into Urartian-controlled territory, was probably not all that huge, given the problems of marching through the mountains and (if Sargon had planned to invade hostile country from the beginning) of securing enough food in enemy land. It would have been time-consuming and dangerous to have a large army navigate difficult narrow mountain passes that would very frequently allow marching only in single file. Xenophon relates that, because of a narrow mountain path, it took the Greek mercenaries, numbering approximately ten thousand troops at the time, ${ }^{27}$ an entire day, from dawn to well into the night, to complete the ascent and descent of a particular mountain (An. 4.1.5-10). Marching at night in the mountains along difficult paths would not only have endangered individual lives but placed the entire army in unnecessary peril: a single rock coming loose easily triggers a slide that could kill whoever is further down the slope and moreover obliterate the path, and the danger of a misstep is multiplied in the darkness. With the logistics of movement in mind, it would have made sense for Sargon to take as small as possible a force into the Zagros. On the other hand, the army had to be large enough to intimidate and, if necessary, face the enemy in battle. For the 714 campaign, this is the Urartian king and his allies. Although very few figures for the Urartian forces exist it is clear that they are very sizeable, as one Assyrian spy report from the reign of Sargon II relates how one provincial governor was in command of three thousand troops (SAA 5: 88). As well as conducting battle successfully, the Assyrian forces had to be large enough to intimidate the inhabitants of the settlements the army came across in enemy territory, so that they would flee, leaving their food stores free for the army to plunder. This was absolutely vital to the army's survival and occurred throughout the 714 campaign (Sg.8 lines 174-177, 190-195, 213-214, 250-252, 290-295). Xenophon's Ten Thousand also relied on this technique for survival, and he describes, uncannily like the narrative of Sg.8, how the inhabitants "fled into the mountains with their women and children," and that "plenty of food remained for the Greeks to take," for food was "a matter of necessity, and they (i.e., the army) took whatever they came across" (An. 4.1.8-9) ${ }^{28}$ This demonstrates that the inhabitants of towns could be successfully intimidated by

26. A number of letters from the Assyrian official Aššur-reșuwa, based in the vassal state of Kumme, located between Urartu and Assyria in the Taurus Mountains (Radner 2012: 254-57), report on the situation in Urartu. Assyrian spies had managed to penetrate deep into Urartu, for one letter includes an order from Sargon that demands that spies are sent to the Urartian capital Țurušpa (SAA 5: 85). Other letters include reports on the movements of the Urartian king, the army and governors, or mention scouts being sent into Urartian territory (e.g., $S A A$ 5: 86, 87, 88, 90, 91, 92). On the extent of the Assyrian espionage activities directed against Urartu and its allies during the reign of Sargon II, see Dubovský 2006b: 32-72 and cf. Dezsö 2014.

27. According to Xenophon, the Greek army was 12,900 strong prior to the Battle of Cunaxa (An. 1.7.10) and was 9,800 strong when reviewed near Trapezus (An. 4.8.15). Allowing for losses at Cunaxa and subsequent desertions, it seems therefore likely that the Greek army consisted of approximately 10,000 soldiers at the time of the ascent of the mountain described here. For an analysis of the strength of the Greek forces during the Anabasis, see Lee 2007: 290 (table 2).

28. For a similar description in the account of Sg.8, see, e.g., lines 213-214, in which the inhabitants of Ulhu and the surrounding area flee into the mountains. Another similarity between Xenophon's Anabasis and Sg.8 is the description of mountaintop watchtowers and fire signals, used by the locals as warning signals (An. 4.1.11; Sg.8 lines 247-252). Such buildings may be attested archaeologically: Muscarella 1986 : 469. 
approximately ten thousand troops, and one could therefore argue that Sargon's army may not have been much larger than this. It is entirely possible that the Urartian forces outnumbered the Assyrians in the encounter on Mount Wauš, which, after all, was decided by a risky surprise attack on Rusa when least expected. But otherwise, Sargon was certainly careful not to overstretch his army, for we hear that although his forces managed to seize a section of the formidable Urartian fortress of Uaiais, he did not attempt, or at least did not succeed, in capturing it fully (Sg.8 lines 297-305).

The moment the army ventured into enemy territory the king and his troops had to live off the land. In 714, this was the case as soon as Sargon left his Mannean base at Panziš and entered Zikirtu, a region formerly part of Mannea but now under separate rule and staunchly allied with Urartu. We hear that Sargon captured twelve fortified cities of Zikirtu, as well as eighty-four smaller towns in the region, and tore down their walls and set fire to the houses (Sg.8 lines 87-90). The archaeology of Mannea (and separatist Zikirtu) has only recently started to emerge in excavations in the area south of Lake Urmia, in the Iranian provinces of western Azerbaijan and Kurdistan, ${ }^{29}$ but while it is currently impossible to identify any sites with their ancient names, there is every hope that this will change as work progresses.

The Assyrian army did not only cause destruction in these areas, but they looted them extensively too, and ate whatever they found in each settlement. In the next description of captured cities, those in the district of Uišdiš, near the Mannean border with Urartu, we hear that Sargon "opened up their innumerable granaries and fed my army unlimited quantities of grain” (Sg.8 1.166). This key phrase appears seven times throughout Sargon's march through hostile territory, at regular intervals in the district of Uišdis (Sg.8 1. 166), in the city of Aniaštania (1. 186), in the region of Bari with the cities of Tarui and Tarmakisa (1.197), in the city of Ulhu (1. 219) and in the region of Sangibutu (lines 262-264). This information makes it clear that the army relied on enemy granaries for survival. We can therefore assume that whenever the Assyrian forces seized a town, however big or small, its supplies of food and drink would be consumed, with a small amount probably packed away as travel provisions, even if the account of Sg. 8 does not explicitly say so. ${ }^{30}$ In fact, the Assyrian soldiers are called "locusts," a description also used by the Bible (Nahum 3:16), because they entered the storehouses of towns as "swift plundering troops" (Sg.8 1.256).

There is no concrete information as to how much grain the Assyrian army could expect to find in the granaries of this region. A total of twenty-two inscriptions from Urartian granaries (Urartian 'ari) ${ }^{31}$ have been found so far, which state the maximum storage capacity of the granary. Although they are all from the north and center of the kingdom of Urartu, regions which Sargon did not visit during the 714 campaign, they can still give us some idea of the size of the granaries which Sargon's army may have come across. The attested granaries vary greatly in size, from 1,432 kapi $\left(\approx 21,193\right.$ liters $\left.^{32}\right)$ to 32,057 kapi $(\approx 474,443$ liters $)$. There seems to have been no standard size, although granaries of 10,100 kapi were evidently preferred at the fortress of Erebuni (Arin-berd in modern Yerevan), located in the north of the kingdom. Several cities had more than one granary. ${ }^{33}$ For example, Erebuni had granaries built by kings Argišti I, Sarduri II and Rusa II, and if all of them were operational at the same time by the time of the last king, the combined total capacity of these attested granaries would have been 72,548 kapi, which equates to an enormous $1,073,710$ liters.

During the unforgiving Zagros winters substantial granaries were needed to supply the population with food, and in early autumn, at the time of Sargon's march through the region, the granaries would already have been well

29. In Western Azerbaijan province: Qalaichi Tepe (also known as Haidar Khan Qal'e; Mollazadeh 2008; Hassanzadeh and Mollasalehi 2011; Nezamabadi 2011) and Qal'e Bardine (Hassanzadeh 2009) in the county of Bukan, Rabat Tepe (Kargar and Binandeh 2009; Reade and Finkel 2014) in the county of Sardasht, all settlement sites; in Kurdistan province: the cemetery of Kul Tarike (Rezvani and Roustaei 2007).

30. Xenophon's Ten Thousand also relied on towns and villages for food. We hear that the army had to continue marching through a storm because, being low on supplies, they had to reach another village (An. 4.1.15), and that Chirisophus, a Greek general, became angry and beat a local guide because he had not led the army to any villages in three days of marching (An. 4.6.2-3).

31. Zimansky 1985: 74; Payne 2005: 6; references: Salvini 2008: 2:63-64

32. Based on Payne's conclusion that 1 kapi $=14.8$ liters: Payne 2005: 89-91.

33. For references see Payne 2005: 92 (table 30). 
stocked as the local people prepared for the winter months. Even if the main settlements did not, for whatever reason, supply the Assyrian forces with all they needed, there were always the smaller towns and villages in their vicinity which the army could easily pillage, such as the thirty towns in the environs of the seven strong cities" in Armarili (Sg.8 1. 272), and the eighty-seven towns in the environs of the "thirty strong cities" in Aiadi (Sg.8 line 286-293). A granary comparable to the smallest recorded Urartian size-that of 1,432 kapi (21,193.6 liters) at Armavir-would still have easily supplied enough food for a day or two for an army that was, say, ten thousand head strong. The itinerary described in Sg.8 shows Sargon moving from district to district, locating sizeable, often very rich, towns in each one. The descriptions of Sg.8 suggest that a number of the towns taken had very substantial reserves indeed. The towns of Tarui and Tarmakisa in the Urartian region of Sangibutu served as fortified storehouses in the plain of Dalaia and were also utilized as stables for the Urartian royal cavalry (Sg.8 lines 188-98). Not only were these towns full of grain, but also fodder, and so would have provided all sections of the army with vast quantities of food and supplies. Still in Sangibutu, Sargon plundered the royal city of Ulhu - certainly well known to the captured members of the royal family. Ulhu had a palace, great storerooms, as well as wine cellars. The capacity of the wine cellars (Urartian $g_{i} e^{34}$ ) in Urartian fortresses could be enormous, as is clear from those excavated at Teišebaini (modern Karmir-blur near Yerevan), whose total capacity of 600 aqarqi corresponds to some 150,000 liters. ${ }^{35}$ At such places, the Assyrian army would have certainly found more than enough food and drink. Therefore, although absolute numbers remain elusive both for the size of the army and the granaries, Sargon clearly had little trouble feeding his troops in Urartian-controlled territory.

The account of Sg. 8 offers a unique and exquisitely detailed description of the Assyrian army plundering the granaries of Sangibutu. It is so important that it deserves to be quoted in full:

I had my whole army carry away on horses, mules, camels and donkeys the large storage piles of barley and wheat which they (i.e., the enemy) had accumulated in granaries over a long time for the sustenance of land and people, and I heaped up (the grain) inside my camp like hills. I fed my people abundant food until they were completely full and they joyfully prepared lavish travel provisions for the return march to the land of Assyria (Sg.8 lines 262-264).

This description shows that the plundering of a granary was not a scene of chaos, but was an organized operation involving soldiers and the army's baggage animals. The grain was brought into the Assyrian camp where it was probably weighed and processed, and although Sg.8 does not describe how the grain was prepared, pictorial evidence from the ninth to the seventh century BCE frequently shows the preparation of food in camp. ${ }^{36}$ For example, the depictions on the bronze strips holding together the Balawat Gates, created in the reign of Shalmaneser III, illustrate the threshing of grain and what seems to be the kneading of dough ${ }^{37}$ and a palace relief from Kalhu showing the camp of Assurnașirpal II illustrates bread being baked in an oven. ${ }^{38}$ Other depictions show the butchering of meat. ${ }^{39}$

The preparation of food in camp was evidently a major task, for there was hardly anything more important on campaign than ensuring that the army was fed and watered. Who carried out this vital task? The answer to this question is supplied by the already mentioned report on an incomplete muster of Sargon's troops in the province of Mazamua (SAA 5: 215). This muster counted 1,430 troops, with 630 of those classed as Assyrian, while 360 were Gurrean and 440 Itu'ean auxiliaries. In the present context, we are concerned with the 630 Assyrians. This

34. Zimansky 1985: 74; Payne 2005: 6; references: Salvini 2008: 2:90-91.

35. Barnett 1959: 1. It is understood that 1 aqarqi is roughly 250 liters: Payne 2005: 82. Wine cellars could be even larger than those at Karmir-blur, for an inscription from the time of Minua (early eighth century BCE) reads that the king built a wine cellar which could hold 900 aqarqi, approximately 225,000 liters: Payne 2005: no.T.B.27.

36. For a detailed and fully illustrated study on food preparation in the Assyrian camp, see Fales and Rigo 2014.

37. King 1915: pl. LI (Band IX.4); Schachner 2007: pls. 9, 46a; cf. Fales and Rigo 2014: 433, figs. 26 and 27.

38. Layard 1849: pl. 30; cf. Fales and Rigo 2014: 434, fig. 28.

39. E.g., on a palace relief from Nineveh from the reign of Assurbanipal: Barnett 1976: pl. LXVI: Slab B fragment c; cf. Fales and Rigo 2014: 435, fig. 40 . 
group included chariotry and cavalry forces, but the most important group for our purpose is the group of 69 domestics (UN.MEŠ-É = nišē-bēti, literally "people of the house"), which included 8 menservants (LÜ*.šá-É-2-e

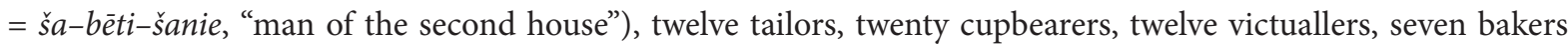
and ten butchers (cooks). The presence of this support staff make it clear that there must have been a significant number of noncombatants in the army, for this number equates to just under 11 percent of the Assyrian forces at Mazamua (Fales 2000: 41). It also allows us to assume that once the grain was brought into camp, the support staff-the victuallers, bakers, and butchers-would begin to prepare food for the army, and it is these people who are shown in the depictions mentioned above. More can be said on the noncombatant element of this muster, however others whose primary duties did not include fighting are mentioned in the muster outside of the "domestic" group. The most obvious ones are the 8 scholars (ummānī), the 23 donkey drivers, the information officer and the 80 mounted scouts, ${ }^{40}$ but we may also add the 53 grooms of the chariot teams and the 130 grooms of the cavalry regiment. On top of these we should perhaps add the fifty-two zunzurharī, a hitherto unidentified profession, for they follow the cavalry grooms in the list. Perhaps they had the responsibility of caring for the horses' tack, such as their reins, harnesses, and armor. If we add all these people together, along with the 69 domestics, we get a total of 416 noncombatants out of 630 Assyrians: 66 percent. Furthermore, perhaps also the non-Assyrian troops, the Gurrean and Itu'ean auxiliaries, included noncombatants. In fact, it seems likely that Gurreans and Itu'eans would have taken part in the food preparations for the entire muster, for it seems unrealistic that the 49 food specialists (20 cupbearers, 12 victuallers, 7 bakers, and 10 butchers) would have been able to prepare food for 630 Assyrians, not to mention the 800 auxiliary troops. ${ }^{41}$ We should consider other noncombatants that are not explicitly listed in the letter but attested otherwise, such as musicians, priests and diviners. In the account of Sg.8, musicians and the offering of sacrifices are described as part of Sargon's triumphal return to camp following his victory over Rusa at Mount Wauš (Sg.8 lines 156-161), and the presence of diviners and astrologers is later on implied by the mention of extispicy and the interpretation of an eclipse prior to Sargon's attack on Musasir towards the end of the campaign (Sg.8 lines 314-319). In addition, there is evidence for exorcists and augurs accompanying the army on campaign. ${ }^{42}$ It is most likely that they all would fall under the category "scholars," of which eight are listed in the Mazamua muster letter. ${ }^{43}$

The impression created by this information is one of a busy, organized camp, and this is also what we see, for example, in a camp scene from a palace relief of Assurnașirpal II, which includes depictions of extispicy and food preparation taking place inside the walls, while outside the camp horses are groomed and fed. ${ }^{44}$ Xenophon's description of the perfectly organized Persian military camp springs to mind, in which the bakers, cooks, horses, baggage animals and soldiers had their own particular sections (Cyr. 8.5.3-6); we may imagine a similarly strict arrangement for the Assyrian camp. The importance of the Assyrian noncombatants and the role of the camp on a long-distance campaign into tough, sometimes unknown, terrain cannot be underestimated. It was these members of the army that allowed the campaign of 714 to run smoothly for approximately five months ${ }^{45} \mathrm{creating}$ an

40. Note that Postgate (2000: 104-5) suggests that the 80 kallāpi (here translated as "mounted scouts"; see Radner 2002: 11) may in fact be standard Assyrian infantry but this is unlikely: see the detailed discussion of Fales 2009: 88-91. Scurlock (2014) proposes a translation as "mounted lancer" but in our assessment, the available sources (conveniently assembled by Scurlock) suggest that a kallappu is on horseback and chiefly concerned with intelligence and surveillance rather than fighting.

41. See also Fales and Rigo 2014: 421.

42. Exorcists were responsible for the wellbeing of troops and horses, as demonstrated by rituals against disease, some of which were to be performed "in the camp" and therefore during military campaigns: Maul 2013: 18. On augurs travelling with the Assyrian army, see Radner 2009: 235 (on SAA 5: 163).

43. Note also the scholars in a letter from Sargon's state correspondence that accompany the army on a campaign in the Zagros kingdom of Ellipi: SAA 1: 14 .

44. British Museum, ME 124548: Layard 1849: pl. 30; detail reproduced in Fales and Rigo 2014: 432, fig. 19 (BM 124548). Note also the veterinary care for horses attested as part of the tasks of exorcists travelling with the army; see Maul 2013: 17-19.

45. As discussed, Sargon departed from Kalhu sometime in late June or early July, and the eclipse mentioned near the end of the campaign (Sg.8 317-319) can be dated to 24th October 714: Oppenheim 1960: 137. 


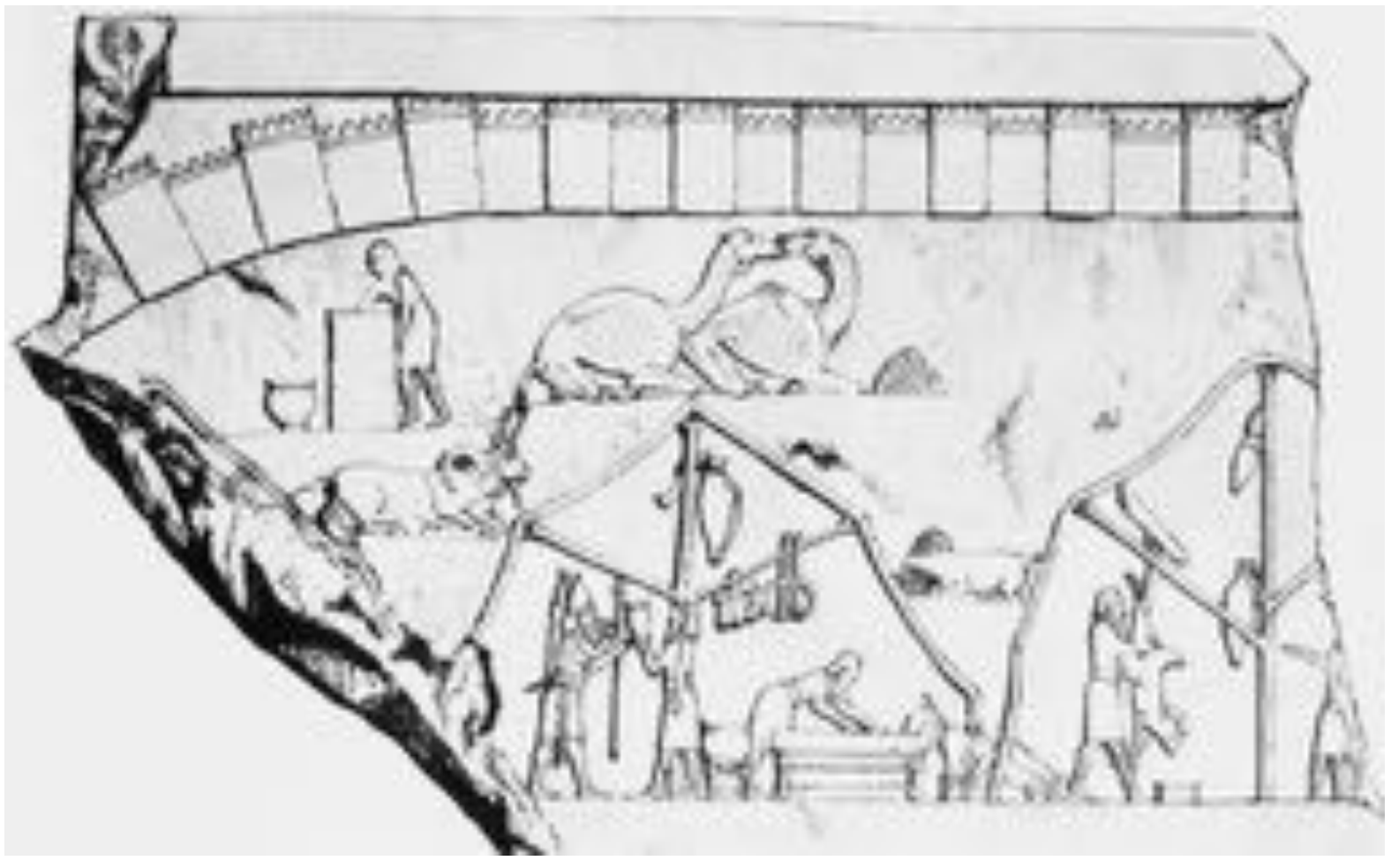

Fig. 2. An Assyrian camp scene showing the inside of a tent: one noncombatant hands a drink to an armed soldier while another is preparing the bed. Detail from a relief fragment of the North Palace of Assurbanipal at Nineveh, found in Room S (slab B), now kept in the Vorderasiatisches Museum Berlin (VA 965). After Barnett (1976) pl. LXVI (Or. Dr. V 26).

environment of comfort and security within enemy territory. The muster at Mazamua was incomplete when the report was written, and we should therefore be cautious in assuming that two-thirds of the entire Assyrian army consisted of noncombatants. But we would nevertheless suggest that the ratio of noncombatants might not have been far off two-thirds for a far-reaching campaign into enemy lands, where the army was completely cut off from the supplies of the empire. In fact, we would argue that it was the support staff that formed the backbone of the army for such a campaign, for it is clear that the soldiers must have relied heavily on these members of the army. The symbiosis between these two types of troops can be seen in a relief from the time of Assurbanipal (Fales and Rigo 2014: 436, fig. 51), in which an armed soldier, perhaps returning from battle, enters his tent and is offered a drink by a noncombatant, while another is preparing the warrior's bed (fig. 2). ${ }^{46}$

The noncombatants' responsibilities in camp freed the fighters to focus on their own particular duties. Their main job was to fight, but during the 714 campaign actual fighting is rarely mentioned or even alluded to, and the account of Sg.8 makes it clear that the expected set of tasks was much more varied. Soldiers could be employed to help the army through difficult mountain passes, widening the passes with copper picks and axes (Sg.8 lines 24; 329), but most of the time we hear how soldiers destroyed and plundered the towns they came across. Alongside food, also items of value were taken, for we hear that Sargon's soldiers "brought ... property, valuables, and treasure" (Sg.8 line 257), which on occasion included the palaces' roof beams (Sg.8 lines 218; 259). After the soldiers had taken all they could, the destruction of the town began. They tore down the fortifications and completed a settlement's devastation by obliterating its orchards, thereby harming food production for many years (Sg.8 lines

46. Vorderasiatisches Museum Berlin, VA 965: Barnett 1976: pl. LXVI (Or. Dr. V 26); detail reproduced in Fales and Rigo 2014: 436, fig. 51. 
258-268; 276; 296; 303). ${ }^{47}$ Aside from the destructive part of their job, soldiers probably also applied themselves constructively by building the center of Assyrian operations throughout the 714 campaign —-the camp.

The camp is mentioned only six times in the account of Sg.8 (lines 27, 159, 178, 254, 263, 349), ${ }^{48}$ so it is not clear how often a new camp was built during the 714 campaign. A clue may be found in Assurnașirpal II's detailed itinerary of a campaign in 879 through the Țur 'Abdin mountain range (Assyrian Kašiari) that separates the Mesopotamian plain from the Upper Tigris Valley. ${ }^{49}$ The army spent six days in the region, and the itinerary explicitly states that the army pitched camp at a different town every day. ${ }^{50}$ The only exception was Matiatu (modern Midyat), the region's most prominent settlement, where the Assyrian army spent two days, for on the first day Matiatu was captured and on the second day the camp was used as a base from which the army could launch attacks against other towns in the vicinity (RIMA 2, A.0.101.19, lines 43-54). Although the environments of the TTur 'Abdin and southwestern Urartu have their differences, with the latter having sizable pockets of arable land, we may use the details from Assurnașirpal's itinerary to reconstruct how Sargon's army may have moved through Urartian-controlled territory. Sargon's army may have advanced just as quickly as Assurnașirpal's, relocating camp every day or two. While stationed at a particularly rich area, such as Ulhu (Sg.8 lines 199-232), the army probably used the camp as a base from which to attack smaller settlements, exactly as Assurnașirpal had used his camp at Matiatu. Finding a good place to camp was of the utmost importance, in terms of feeding the army and of security and Sargon probably relied on his captive Urartian guides to lead him to the best places to encamp-which they seem to have done-but the king would have had the final say on where his army should set down for the night. That the king involved himself in such decisions is demonstrated by a letter from Sargon to an official, in which the king recommends that his correspondent set up camp at the city of Urammu on the Elamite border, because "there is a plain which is very good for encamping; it is also very good for reconnaissance expeditions, there is much grass there, and it is a good place to rest" (SAA 1: 13, lines 5-19).

In 714, the army had to be back in Assyria before the mountain passes became blocked with snow. Speed was therefore of considerable importance. Sargon, like Assurnașirpal II in 879 in the Tur 'Abdin mountains, may have spent just a day or two at each major town. This is inherently likely not only because of their dependence on the local granary provisions, but also because the element of surprise was central to the success of his intimidation tactics. If a town's inhabitants had enough forewarning of the Assyrian attack they might have prepared a resistance, which would make a battle with the Assyrians much more likely. However, if the army moved quickly the inhabitants would be more likely to be caught off guard and flee into the mountains. Conversely, the enemy could not rally and attack the encamped Assyrians. The campaign of 714 was an operation of consumption, destruction and looting, not of conquest, and survival and safety of the army were key concerns, for the king was careful not to place his troops in a situation with unnecessary risk, particularly because he relied on the army for his personal security during such a campaign.

47. See Hansen and Nielsen 2004: 135-37 for the idea that, in the ancient Greek world, walls were a vital element of being a polis, and city walls may have held similar importance in the ancient Near East. If so, the destruction of the walls would be an ideological assault on the inhabitants, essentially dehumanizing them, and would also leave them open to any further attack. The destruction of the orchards is similar, for it removes a key part of the inhabitants' self-sufficiency. See Cole 1997.

48. While Sargon states that he did not build a camp before attacking Rusa (Sg.8 1. 129), he returns to camp after claiming victory in the battle (Sg.8 1. 159). How are we to imagine this? It may be that the account claims that no camp was built only to heighten the drama of the narrative (see already n. 25 on the dubious nature of the battle report), or, if we take the passage literally, we may assume that while the king and his troops fought the battle, the noncombatants started work on the camp.

49. The most detailed text is RIMA 2, A.0.101.19, lines 35-63. For studies of this campaign see Liverani 1992: 57-62 and Radner 2006b: $286-91$.

50. The inscription reads that the army "pitched camp and spent the night" at a town, and the next day the army moves on and approaches another settlement: RIMA 2, A.0.101.19, lines 40-41, 43, 54-55, 56-57, 58. Note that the last night was spent at an unnamed location in the mountains. 


\section{Conclusions}

From our discussion, the army which Sargon took on campaign in 714 emerges not as an unstoppable fighting machine formed of war-hungry warriors, but a far more heterogeneous group of specialists, whose skills allowed the army to function smoothly for months, far away from the empire. They relied on intimidation, not brute force, to seize enemy settlements, and the troops relatively rarely engaged in combat.

Speed, safety, and access to resources were the three things the Assyrian army required to successfully complete a campaign into unknown territory, more so if the terrain was expected to be difficult and hostile. Planning and strict organization were therefore paramount, as the army needed to be delicately balanced in its size and its composition. If the army was too large then it would have been a struggle to feed every soldier and navigating narrow mountain paths in single file could take up days. On the other hand, if the army was too small then it would not have been able to secure enemy food stores by force or intimidation. Similarly, if there were too few noncombatants, food preparation and the care of the animals would have been disrupted, putting the whole campaign and the wellbeing of the entire army in jeopardy.

The decisions made by the king and his advisors in preparation for a military campaign ${ }^{51}$ were therefore immensely important for its success. The oracle queries to the sun-god Šamaš, patron deity of extispicy, from the reign of Sargon's grandson and second successor Esarhaddon (r. 680-669 BCE) indicate that the king would ponder safety issues ${ }^{52}$ and possible outcomes of planned campaigns into dangerous terrain ${ }^{53}$ and against a strong enemy. ${ }^{54}$ These queries highlight the fact that the performance of a "risk assessment" in preparation for a campaign was an important procedure, and that the safety of the army was a very serious issue for the king. We see this concern also in the reign of Tiglath-pileser III, when an official urges the king to besiege the Urartian capital Turušpa in order to win eternal glory (SAA 19: 76). The prospect of glory was not enough for the king, however, for no such attack took place - it seems that the king was not willing to risk his army by besieging the enormous, impregnable rock fortress that was Țurušpa (Van Kalesı).

Sargon arguably must have contemplated similar concerns when planning the 714 campaign, although we have no concrete evidence for this. But we see the result, in that an army was raised to suit the challenge, configured so that the ratio of noncombatants to soldiers would allow the army to function away from Assyrian supply lines. Preexisting knowledge gained through the espionage network and the availability of captive Urartians acting as local guides ensured that the army could move swiftly through enemy territory, relocating frequently to a new, safe, and well-resourced location.

As this study has emphasised, Assyrian armed forces were configured in such a way as to create an independent organism suited for the specific task at hand. An army sent across a desert or a force dispatched to conquer a city would therefore take forms markedly different from an expeditionary force sent into the mountains, such as the one mobilized in 714. This army had to be able to move at speed over difficult terrain, to intimidate and plunder,

51. The decision-making process is discussed by Radner 2011.

52. Concern for the army's safety is in evidence in a number of oracle queries from the time of Esarhaddon, in which the king asks the sun god if the army would "return alive and set foot on Assyrian soil" (SAA 4: 62, 64, 72, 79, 80 and 87). The safety of the Chief Eunuch, and his troops, on campaign in Egypt is the subject of an oracle query, asking whether he would be subject to a "dangerous attack," and whether the kings of Egypt would "kill, capture, plunder, or loot him" (SAA 4: 88).

53. Concerned about the safety of the army in unforgiving terrain is in evidence, e.g., when asking the sun god whether the army should go to Egypt (SAA 4: 84 and 85), which would mean crossing the Negev region and the Sinai desert. An inscription which describes the Assyrian invasion of Egypt in 671 highlights the theme of water throughout the narrative, and describes the Sinai as a place where "one is always thirsty", and relates how the army collected water from wells at Raphia by means of ropes and chains (RINAP 4, 34). For a discussion of this campaign and the route taken by the army, see Radner 2008: 305-14.

54. Respect for a dangerous adversary is, e.g., in evidence when asking the sun god whether the army should be sent against Quhna, a fortress controlled by Mugallu of Melid (SAA 4: 7). Although this man was the subject of a number of oracle queries, he is never mentioned in the royal inscriptions of Esarhaddon, which may suggest that the Assyrian army enjoyed very little success against him. 
and to fight if unavoidable. But crucially, this organism had to be capable of offering protection to each of its members and allowing the king and his troops a good chance to return safely to their Assyrian homeland.

\section{Excursus: Food Logistics and Sargon's Route beyond the Zagros Main Ridge}

Locating food provisions would certainly have influenced Sargon's route through Urartian-controlled territory. This vital aspect is mostly ignored in studies focusing on the historical geography of Sargon's route in 714, and in light of our conclusions regarding the army's method of obtaining food we therefore offer a brief critique of the three main routes that have been suggested. ${ }^{55}$

The first route suggestion takes the Assyrian forces in a giant circuit around the east coast of Lake Urmia and the west coast of Lake Van. While locating food would not have been difficult on such a march, this route appears far too long, especially when the time constraints are considered: the Assyrians needed to be back at the western side of the Zagros before the first snow appeared in the mountains. The army would also have needed to watch its flanks: although Rusa had been defeated in battle, it would have been foolish to believe that the Assyrian forces would be free from attack and possible encirclement in the very heart of Urartu (Levine 1977: 146-48).

The second proposal is the "circum-Urmia" route around Lake Urmia. For Zimansky (1990: 14), there is "no theoretical objection to a march around the lake" and he argues in favor of this, citing passages in the account of Sg.8, which state that Sargon entered Urartian territory at its "head" (Sg.8 line 167), and left through its "foot" (Sg.8 line 298, Zimansky 1990: 10-11). This could be taken to suggest a north-south route, entering Urartu from the northeast of Lake Urmia, but this phrasing can easily be seen as a figure of speech, as also Zimansky (1990: 21) concedes. The most serious problem with the circum-Urmia route is the near total nonexistence of Urartian settlements along the east coast of Lake Urmia. ${ }^{56}$ Zimansky (1990: 9) noted this, but he did not recognize the seriousness of this problem for reconstructing the 714 campaign in this region. If we take into account that the Assyrian army survived by seizing the local grain stores then it seems impossible that Sargon's troops marched along the east coast of Lake Urmia as they would have had tremendous difficultly procuring enough food. Moreover, the circum-Urmia route does not make much sense on a tactical level. Having defeated Rusa in battle, it can be argued that Sargon would have been tempted to exploit Rusa's weakness and put more pressure on him. The best way to do this would be by invading his territories whereas a march along the east coast of Lake Urmia, where no Urartian settlements were located, would in fact relieve pressure from Rusa.

The third proposed route sees Sargon march through the area to the southwest of Lake Urmia and is by far the most likely. In contrast to the dearth of settlements along the east coast of the lake, the area to the southwest of Urmia is clustered with them, ${ }^{57}$ meaning that there would have been plenty of towns to seize and plunder, exactly as the account of Sg.8 describes. Following this route would also have allowed Sargon to return to Assyria within the necessary time constraints. The threat to the army's flanks and the danger of encirclement would have been vastly diminished. When imagining the part of the 714 campaign beyond the Zagros main ridge, we best envisage a march around the rich, agricultural area to the southwest of Lake Urmia, home to a large number of settlements.

55. For a map of the main proposed routes, see Zimansky 1990: 6 .

56. For maps that plot Urartian settlements, see those included in Kleiss and Hauptmann 1976; Kroll et al. 2012: 23, fig. 01.13; and Salvini 2008.

57. See n. 56 for maps showing Urartian settlements. 


\section{References}

Altaweel, M.; Marsh, A.; Mühl, S.; Nieuwenhuyse, O.; Radner, K.; Rasheed, K.; and Saber, S. A.

2012 New Investigations in the Environment, History and Archaeology of the Iraqi Hilly Flanks: Shahrizor Survey Project 2009-2011. Iraq 74: 1-35.

Barnett, R. D.

1959 Further Russian Excavations in Armenia (1949-1953). Iraq 21: 1-19.

1976 Sculptures from the North Palace of Ashurbanipal at Nineveh (668-627 BC). London: British Museum Publications.

Borger, R.

1996 Beiträge zum Inschriftenwerk Assurbanipals. Wiesbaden, Harrassowitz.

Botta, P.-É., and Flandin, E.

1850 Monument de Ninive. 2 vols. Paris: Imprimerie Nationale.

Cole, S. W.

1997 The Destruction of Orchards in Assyrian Warfare. Pp. 29-40 in Assyria 1995, ed. S. Parpola and R. M. Whiting. Helsinki: Neo-Assyrian Text Corpus Project.

Dezsö, T.

2014 Neo-Assyrian Military Intelligence. Pp. 221-35 in Krieg und Frieden im Alten Vorderasien, ed. H. Neumann et al. Münster: Ugarit-Verlag.

Dietrich, M.

2003 The Babylonian Correspondence of Sargon and Sennacherib. SAA 17. Helsinki: Helsinki University Press.

Driel, G. van

1992 Weather Between the Natural and the Unnatural in First Millennium Cuneiform Inscriptions. Pp. 39-52 in Natural Phenomena: Their Meaning, Depiction, and Description in the Ancient Near East, ed. D. Meijer. Amsterdam: Royal Netherlands Academy of Arts and Sciences.

Dubovský, P.

2006a Hezekiah and the Assyrian Spies: Reconstruction of the Neo-Assyrian Intelligence Services and its Significance for 2 Kings 18-19, Rome: Pontificio Instituto Biblico.

2006b Conquest and Reconquest of Muṣașir in the 8th Century BCE. SAAB 15: 141-46.

Fales, F. M.

1990 Grain Reserves, Daily Rations, and the Size of the Assyrian Army: A Quantitative Study. SAAB 4: 23-34.

1991 Narrative and Ideological Variations in the Account of Sargon's Eighth Campaign. Pp. 129-47 in Ah, Assyria... Studies in Assyrian History and Ancient Near Eastern Historiography Presented to Hayim Tadmor, ed. M. Cogan and I. Ephal. Jerusalem: Magnes.

2000 Preparing for War in Assyria. Pp. 35-62 in Économie antique: la guerre dans les economies antiques, ed. J. Andreau et al. Saint-Bertrand-de-Comminges: Musée archéologique départemental.

2009 The Assyrian Words for "(Foot) Soldier." Pp. 72-94 in Homeland and Exile: Biblical and Ancient Near Eastern Studies in Honour of Bustenay Oded, ed. G. Galil et al. Leiden: Brill.

Fales, F. M., and Rigo, M.

2014 Everyday Life and Food Practices in Assyrian Military Encampments. Pages 413-37 in Palaeonutrition and Food Practices in the Ancient Near East: Towards a Multidisciplinary Approach, ed. L. Milano. Padova: Sargon.

Foster, B. R.

2005 The Eighth Campaign. Pp. 790-813 in Before the Muses: An Anthology of Akkadian Literature. 3rd ed. Bethesda: CDL.

Frame, G.

in press The Royal Inscriptions of Sargon II, King of Assyria (721-705 BC). RINAP 2. Winona Lake: Eisenbrauns.

Fuchs, A.

1994

Die Inschriften Sargons II. aus Khorsabad, Göttingen: Cuvillier.

2005 War das Neuassyrische Reich ein Militärstaat? Pp. 35-60 in Krieg, Gesellschaft, Institutionen: Beiträge zu einer vergleichenden Kriegsgeschichte, ed. B. Meißner et al. Berlin: Akademie Verlag.

2009 Sargon II. RlA 12.1-2:51-61.

2012 Wissenstransfer und -anwendung im Bereich des Heerwesens und der Militärtechnik des neuassyrischen Reiches. Pp. 31-59 in Wissenskultur im Alten Orient: Weltanschauung, Wissenschaften, Techniken, Technologien, ed. H. Neumann. Wiesbaden: Harrassowitz. 
Fuchs, A., and Parpola, S.

2001 The Correspondence of Sargon II, Part III: Letters from Babylonia and the Eastern Provinces. SAA 15. Helsinki: Helsinki University Press.

Grayson, A. K.

1987 Assyrian Rulers of the Third and Second Millennia BC (to 1115 BC) RINAP 1. Toronto: University of Toronto Press.

1991 Assyrian Rulers of the Early First Millennium BC I (1114-859 BC) RINAP 2. Toronto: University of Toronto Press.

1996 Assyrian Rulers of the Early First Millennium BC II (858-745) RINAP 3. Toronto: University of Toronto Press.

Hansen, M. H., and Nielsen, T. H., eds.

2004 An Inventory of Archaic and Classical Poleis. Oxford: Oxford University Press.

Hassanzadeh, Y.

2009 Qal'e Bardine, a Mannaean Local Chiefdom in the Bukan Area, North-Western Iran. Archäologische Mitteilungen aus Iran und Turan 41:269-82.

Hassanzadeh, Y., and Mollasalehi, $\mathrm{H}$.

2011 New Evidence for Mannean Art: An Assessment of Three Glazed Tiles from Qalaichi (Izirtu). Pp. 407-17 in Elam and Persia, ed. J. Alvarez-Mon and M. B. Garrison. Winona Lake, IN: Eisenbrauns.

Hurowitz, V. A.

2008 "Shutting up" the Enemy: Literary Gleanings from Sargon's Eighth Campaign. Pp. 104-20 in Treasures on the Camels' Humps: Historical and Literary Studies from the Ancient Near East Presented to Israel Ephial, ed. M. Cogan and D. Kahn. Jerusalem: Magnes.

Kargar, B., and Binandeh, A.

2009 A Preliminary Report Of Excavations at Rabat Tepe, Northwestern Iran. IrAn 44: 113-29.

Kessler, K.

2013 Kār Aššur, Chalas(s)ar, Artemita. Pp. 273-284 in Kleine Götter - Große Götter: Festschrift für Dieter Kessler zum 65. Geburtstag, ed. M. C. Flossmann-Schütze et al. Tuna el-Gebel 4. Vaterstetten: Patrick Brose.

King, L. W.

1915 Bronze Reliefs from the Gate of Shalmaneser, King of Assyria 860-825 BC. London: British Museum.

Kleiss, W., and Hauptmann, H.

1976 Topographische Karte von Urartu. Archäologische Mitteilungen aus Iran Ergänzungsband, 3. Berlin: Reimer.

Kravitz, K.

2003 A Last-minute Revision to Sargon's Letter to the God. JNES 62: 81-95.

Krentz, P.

2008 War. Pp. 147-85 in The Cambridge History of Greek and Roman Warfare I: Greece, the Hellenistic World and the Rise of Rome, ed. P. Sabin et al. Cambridge: Cambridge University Press.

Kroll, S.; Gruber, C.; Helwag, U.; Roaf, M.; and Zimansky, P.

2012 Introduction. Pp. 1-38 in Biainili-Urartu, ed. S. Kroll et al. Acta Iranica 51. Leuven: Peeters.

Lanfranchi, G., and Parpola, S.

1990 The Correspondence of Sargon II, Part II: Letters from the Northern and Northeastern Provinces. SAA 5. Helsinki: Helsinki University Press.

Layard, A. H.

1849 The Monuments of Nineveh: Drawings Made on the Spot, First Series, London: John Murray.

Lee, J. W. I.

2007 A Greek Army on the March: Soldiers and Survival in Xenophon's Anabasis. Cambridge: Cambridge University Press.

Leichty, E.

2011 The Royal Inscriptions of Esarhaddon, King of Assyria. RINAP 4. Winona Lake, IN: Eisenbrauns.

Levine, L. D.

1969 Contributions to the Historical Geography of the Zagros in the Neo-Assyrian Period. PhD diss., University of Pennsylvania.

1977 Sargon's Eighth Campaign. Pp. 135-51 in Mountains and Lowlands: Essays in the Archaeology of Greater Mesopotamia, L. D. Levine and T. Cuyler Young. BM 7. Malibu: Undena.

Liverani, M.

1992 Studies on the Annals of Ashurnasirpal II 2: Topographical Analysis, Rome: Università di Roma.

Luukko, M.

2012 The Correspondence of Tiglath-pileser III and Sargon II from Calah/Nimrud. SAA 19. Helsinki: Neo-Assyrian Text

Corpus Project. 
Maul, S. M.

2013 Ein altorientalischer Pferdesegen: Seuchenprophylaxe in der assyrischen Armee. ZA 103: 16-37.

Mayer, W.

1983 Sargons Feldzug gegen Urartu-714 v. Chr.: Text und Übersetzung. MDOG 115: 65-132.

2013 Assyrien und Urartu I: Der Achte Feldzug Sargons II. im Jahr 714 v. Chr. AOAT 395.1. Münster: Ugarit-Verlag.

Mollazadeh, K.

2008 The Pottery from the Mannean Site of Qalaichi, Bukan (NW-Iran). IrAn 43: 107-25.

Moorey, P. R. S.

1994 Ancient Mesopotamian Materials and Industries: The Archaeological Evidence. Oxford: Clarendon.

Muscarella, O. W.

1986 The Location of Ulhu and Uiše in Sargon II's Eighth Campaign, 714 B.C. JFA 13: 465-75.

Na’aman, N.

1974 Sennacherib's "Letter to God" on His Campaign to Judah. BASOR 214: 25-39.

Nezamabadi, $\mathrm{M}$.

2011 Mannaean Faunal Remains from Tepe Qalaichi, Northwestern Iran (9th-7th B.C.). Journal of Iranian Archaeology 2: $33-40$.

Oppenheim, A. L.

1960 The City of Assur in 714 B.C. JNES 19: 133-47.

Parpola, S.

1987 The Correspondence of Sargon II, Part I: Letters from Assyria and the West. SAA 1. Helsinki: Helsinki University Press.

Payne, M.

2005 Urartian Measures of Volume. Leuven: Peeters.

Postgate, J. N.

2000 The Assyrian army in Zamua. Iraq 62: 89-108.

Radner, K.

2002 Die neuassyrischen Texte aus Tall Šęh Hamad. Beiträge zu den Ausgrabungen von Tall Šēh Hamad 6. Berlin: Reimer.

2003 An Assyrian View on the Medes. Pp. 37-64 in Continuity of Empire (?): Assyria, Media, Persia, ed. G. Lanfranchi, M. Roaf, and R. Rollinger. Padova: Sargon.

2006a Provinz. C. Assyrien. RLA 11/1-2: 42-68.

2006b How to Reach the Upper Tigris: The Route Through the Tur Abdin. SAAB 15: 273-305.

2008 Esarhaddon's Expedition from Palestine to Egypt in 671 BCE: A Trek through Negev and Sinai. Pp. 305-14 in Fundstellen: Gesammelte Schriften zur Archäologie und Geschichte Altvorderasiens ad honorem Hartmut Kühne, ed. D. Bonatz et al. Wiesbaden: Harrassowitz.

2009 The Assyrian King and his Scholars: The Syro-Anatolian and the Egyptian Schools. StOr 106: 221-38.

2011 Royal Decision-making: Kings, Magnates, and Scholars. Pp. 358-79 in The Oxford Handbook of Cuneiform Culture, ed. K. Radner and E. Robson. Oxford: Oxford University Press.

2012 Between a Rock and a Hard Place: Mușașir, Kumme, Ukku and Šubria-the Buffer States between Assyria and Urartu. Pp. 243-64 in Biainili-Urartu, ed. S. Kroll et al. Acta Iranica 51. Leuven: Peeters.

2013 Assyria and the Medes. Pp. 442-56 in The Oxford Handbook of Ancient Iran, ed. D. T. Potts. New York: Oxford University Press.

Reade, J., and Finkel, I.

2014 Between Carchemish and Pasargadae: Recent Iranian Discoveries at Rabat. Pp. 581-96 in From Source to History: Studies on Ancient Near Eastern Worlds and Beyond Dedicated to Giovanni Battista Lanfranchi, ed. S. Gaspa et al. AOAT 412. Münster: Ugarit-Verlag.

Reynolds, F. S.

2003 The Babylonian Correspondence of Esarhaddon and Letters to Assurbanipal and Sin-šarru-iškun from Northern and Central Babylonia. SAA 18. Helsinki: Helsinki University Press

Rezvani, H., and Roustaei, K.

2007 A Preliminary Report on Two Seasons of Excavations at Kul Tarike Cemetery, Kurdestan, Iran. IrAn 42: 139-84.

Salvini, M.

2008 Corpus dei testi Urartei: le iscrizioni su pietra e roccia. 3 vols. Rome: Istituto di Studi sulle Civiltà dell'Egeo e del Vicino Oriente. 
Schachner, A.

2007 Bilder eines Weltreichs: kunst- und kulturgeschichtliche Untersuchungen zu den Verzierungen eines Tores aus Balawat (Imgur-Enlil) aus der Zeit von Salmanassar III, König von Assyrien. Turnhout: Brepols.

Scurlock, J.

1997 Neo-Assyrian Battle Tactics. Pp. 491-517 in Crossing Boundaries and Linking Horizons: Studies in Honor of Michael C. Astour, ed. G. D. Young et al. Bethesda: CDL.

2014 kallāpu: A New Proposal for a Neo-Assyrian Military Term. Pp. 725-34 in Krieg und Frieden im Alten Vorderasien, ed. H. Neumann et al. Münster: Ugarit-Verlag.

Starr, I.

1990 Queries to the Sungod: Divination and Politics in Sargonid Assyria. SAA 4. Helsinki: Helsinki University Press.

Thureau-Dangin, F.

1912 Une Relation de la Huitième Campagne de Sargon (714 av. J.-C.). Paris: Geuthner.

Van Buylaere, G.

2009 I Feared the Snow and Turned Back. StOr 106: 295-306

Van De Mieroop, M.

2010 A Study in Contrast: Sargon of Assyria and Rusa of Urartu. Pp. 417-34 in Opening the Tablet Box: Near Eastern Studies in Honor of Benjamin R. Foster, ed. S. C. Melville and A. L. Slotzky. CHANE 42. Leiden: Brill.

Wilson, C.

1895 Handbook for Travellers in Asia Minor, Transcauasia, Persia, etc. London: John Murray.

Zaccagnini, C.

1981 An Urartian royal inscription in the report of Sargon's Eighth Campaign. Pp. 259-95 in Assyrian Royal Inscriptions: New Horizons in Literary, Ideological, and Historical Analysis, ed. F. M. Fales. Rome: Istituto per l'Oriente.

Zimansky, P.

1985 Ecology and Empire: The Structure of the Urartian State. SAOC 41. Chicago: The Oriental Institute of the University of Chicago.

1990 Urartian Geography and Sargon’s Eighth Campaign. JNES 49: 1-21. 
